\title{
INCUBATORS AND MICRO AND SMALL ENTERPRISE GROWTH: A NARRATIVE LITERATURE REVIEW
}

(D) Ahmad Raflis Che
Omar $^{1}$
(D) Suraiya Ishak ${ }^{2+}$
(i) Azima Abdul
Manaf $^{3}$
Nur Shafiqah Mohd
Sabri $^{4}$
Lokhman Hakim $_{\text {Osman }^{5}}$

\author{
${ }^{1,5}$ Centre for Value Creation $\&^{\circ}$ Human Well-Being Studies, Faculty of \\ Economics \& Management, University Kebangsaan Malaysia, Selangor, \\ Malaysia. \\ 'Email: raflis@ukm.edu.my \\ ${ }^{5}$ Email::lokhman@ukm.edu.my \\ ${ }_{2,3,4}$ Centre for Research in Development, Social \& Environmental, Faculty of \\ Social Sciences \& Humanities, University Kebangsaan Malaysia, Selangor, \\ Malaysia. \\ ${ }^{2}$ Email:suraiya@ukm.edu.my \\ ${ }^{s}$ Email:azima@ukm.edu.my \\ Email:p112038@siswa.ukm.edu.my
}

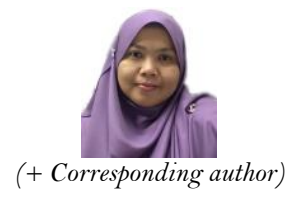

ABSTRACT

This article presents a narrative literature review that aims to accomplish three objectives: (1) to describe the role of external support-namely, the incubator program-in encouraging micro and small business growth; (2) to explain the concept of the incubator program; and (3) to identify the typologies in the execution of entrepreneurial incubator programs. Findings from the review show that external support is required in the early growth of the life cycle indicated by the "growth through creativity" and "growth through direction" phases in the Greiner Growth Model and the "existence" and "survival" stages in the Churchill and Lewis Growth Model. The incubator concept is centered around providing basic, specific amenities and services to support the selected MSEs growth. Incubators are a form of external support that aim to assist the growth of start-up MSEs. Finally, four typologies are identified based on the degree of supervision and range of services offered.

Contribution/ Originality: The originality of the study lies in its attempt to provide an overview of the role of external support and the incubator program in MSEs' growth by integrating organisations' life cycle models. These explanations enrich the understanding of the incubator concept for future researchers.

\section{INTRODUCTION}

Micro and small enterprises (MSEs) are significant players that form the pillars for the domestic economy and contribute to income and employment creation for nations (Zapata-Guerrero, Ayup, Mayer-Granados, \& CharlesColl, 2021). Small and medium enterprises account for almost $99 \%$ of all businesses across Organisation for Economic Cooperation and Development (OECD) countries and between 50-60\% of their value added (SME Corporation Malaysia, 2018). The contributions of MSEs to world economies are acknowledged through the pronouncement of $27^{\text {th }}$ June as World Micro, Small and Medium Sized Enterprises (MSME) Day by the United Nations (SME Corporation Malaysia, 2018). As such, the growth and survival issues of MSEs have become increasingly critical and important (Yap, Syuhaimee, \& Hoe, 2019). Hence, external support in the form of entrepreneurial incubators becomes important for stimulating the growth of MSEs. 
Business incubators primarily refer to a shared office facility designed to provide incubatees with strategic, value-added intervention systems of monitoring and business assistance (Abduh, D'Souza, Quazi, \& Burley, 2007; Hackett \& Dilts, 2004). Nonetheless, incubators refer not only to the provision of office buildings and infrastructure but also include networks of individuals and organisations, including incubator managers and staff, marketing specialists, venture capitalists, incubatee companies and employees, industry contacts, professional services, local universities and volunteers. Business incubators serve as a mechanism for the creation of new ventures, provide legitimacy and networks, increase community support and offer platforms for building a client-based environment, creating perceptions of reduced risk and increased security within the given physical space (Hewitt \& van Rensburg, 2020). According to Akçomak (2009) the body of literature on entrepreneurial incubators can be classified into two broad categories. The first category comprises studies that deal with the theory of incubators, including incubator models, descriptions of how incubators are formed and their aims and management. Meanwhile, the second set consists of studies concerned with indicators defining the success of the incubator program. The current article aims to present insights to provide a holistic understanding of entrepreneurial support programs- that is, incubator programs-by taking into consideration the relevant existing literature. Based on this understanding, this paper presents a narrative review that contributes to a systematic understanding of the incubator concept and its implementation. The current article aims to accomplish three objectives: (1) to describe the role of external support, namely, incubator programs, in encouraging micro and small business growth, (2) to explain the concept of an incubator program, and (3) to identify the typologies in the execution of entrepreneurial incubator programs.

\section{GROWTH LIFE CYCLE MODEL}

Business growth can be viewed from various perspectives (Muhos, 2015). Muhos (2015) presents two perspectives for understanding business growth issues. The first perspective emphasises critical factors leading to the growth and survival of business organisations, which consist of resource-based, motivation and strategic adaptation approaches. Meanwhile, the second perspective concerns the management behaviours (ideal practices) to be adopted throughout the growing cycle. This perspective is known as the growth, life-cycle or configuration perspective. The configuration perspective divides early business growth into specific growth stages or transitions. It suggests that business entities are exposed to diverse managerial problems that are unique to each stage. This specificity involves unique variables including different problems, strategies and priorities in parallel with the relevant growing stages. This diversity leads to numerous models under the configuration perspective.

Table 1. SMEs business growth model.

\begin{tabular}{l|l}
\hline No. & SME growth stage model \\
\hline 1. & Evolution in 5 Phases of Growth Model (Greiner, 1998) \\
\hline 2. & Organisational Passages Model (Adizes, 1979) \\
\hline 3. & Stages of Small Business Growth Model (Churchill \& Lewis, 1983) \\
\hline 4. & Integrated Life Cycle Model (Quinn \& Cameron, 1983) \\
\hline 5. & Corporate Life Cycle Model (Miller \& Friesen, 1984) \\
\hline 6. & Model for Small Business Growth (Scott \& Bruce, 1987) \\
\hline 7. & Structural Variable Model (Hanks, Watson, Jansen, \& Chandler, 1994) \\
\hline 8. & Tipping Point Framework (Phelps, Adams, \& Bessant, 2007) \\
\hline 9. & Organisational Life Cycle Scale (Lester \& Parnell, 2008) \\
\hline 10. & Stage Categories Model (Levie \& Lichtenstein, 2010) \\
\hline Source: Jacobs, Kotzé, and van der Merwe (2017).
\end{tabular}

In the configuration perspective, SME growth is viewed as a series of stages of development through which businesses may pass during their life cycles (Jacobs et al., 2017). There are at least 10 models of SMEs' growth stages see Table 1. These models explain the process of SMEs' growth by linking configuration variables with the particular issues and situations persisting at each transition phase or stage. One of the models for describing business growth life cycles is the Greiner Model. The five stages in the life cycle of a business venture are depicted 
in Figure 1. Larry E. Greniner originally proposed five phases of growth and later added a sixth phase in his updated model (Greiner, 1998). Figure 1 depicts the phases of the Greiner growth model.

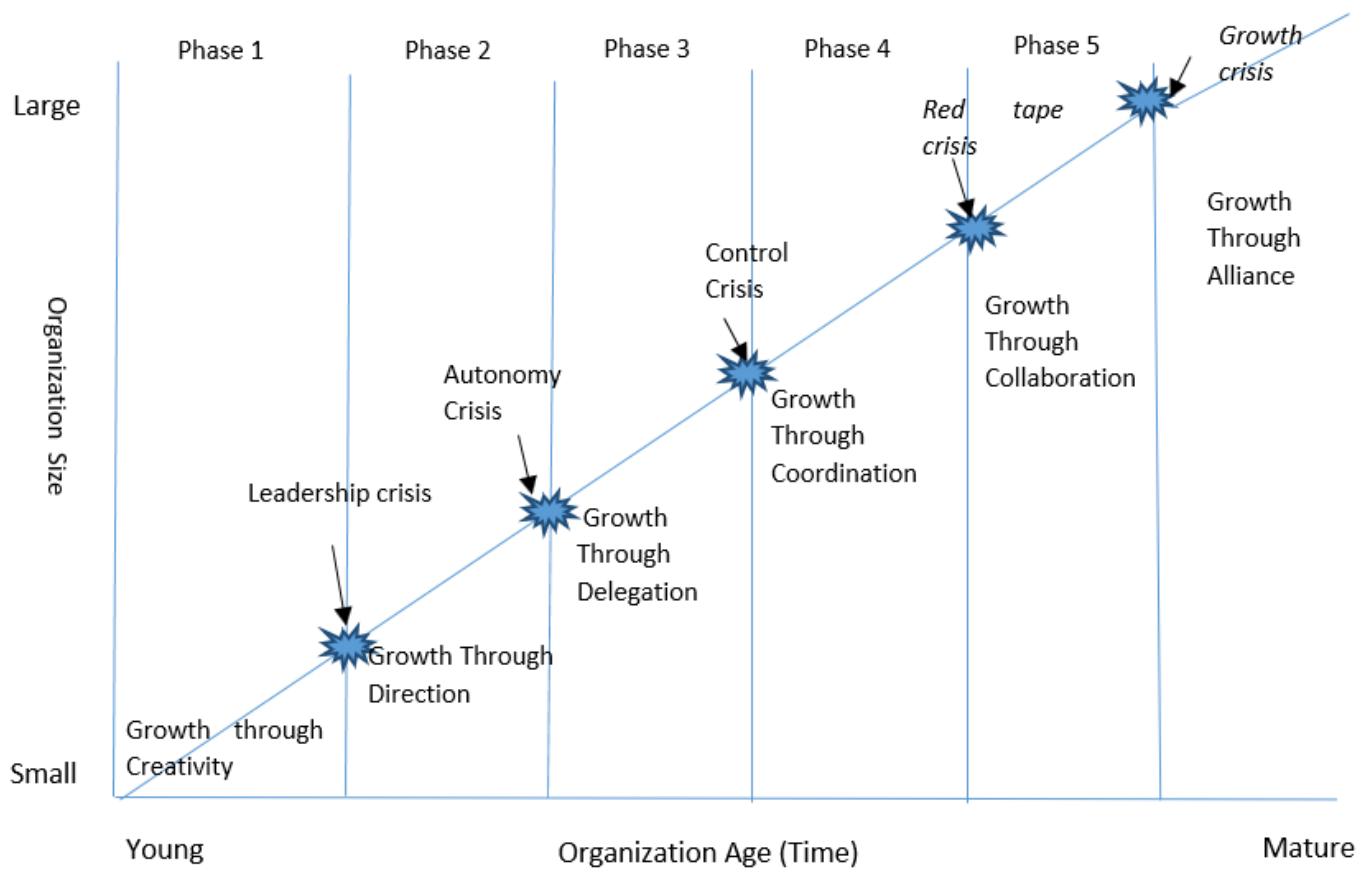

Figure 1. Greiner business growth model.

Greiner proposed that business growth can be examined through the dimensions of size and age. The first phase starts at the beginning, when the business starts to develop through the efforts of the founder. The growth at this phase is known as growth through creativity. In the early phase, the business operation and structure is relatively informal. The size of the business is small, with a minimal numbers of workers. The founders (entrepreneurs) work out the venture with a high entrepreneurial spirit and focus on producing new products and services for the market. As the business expands, the venture begins to encounter problems, such as production inefficiencies, managing an increasing number of workers and finding additional resources to fulfil the needs of the expanding business. At this stage, the business faces a leadership crisis as the current leadership becomes incapable and unable to continue developing the business venture. The businesses that manage to overcome the leadership crisis will merge into the growth through direction phase. In the second phase, the business ventures are more structured and formalised, as specialisation of functional units, standard procedures and organised systems are adopted. Again, as the business grows, another crisis emerges: the autonomy crisis. The entrepreneurs face challenges in coordinating diverse units and activities due to the expanding scope and structure of the organisation. The crisis needs to be resolved through the delegation of authority. Thus, the next growth phase is known as growth through delegation. In the third phase, the functional units are decentralised and each unit is able to perform its tasks efficiently and effectively. To a certain extent, the situation continues into another growth crisis known as the control crisis. This crisis can only be managed by effective coordination to realign the various activities of the entire units. The next growth phase is known as growth through coordination, which leads to a growth crisis known as the red-tape crisis. The red-tape crisis emerged due to the implementation of various coordination tools that eventually distort the business efficiencies. The next growth phase is growth through collaboration. The final crisis in the Greiner model is the growth crisis. At this point, the business entities have reached their maximum internal growth capacity. In order to grow bigger, the venture needs another strategy, which may involve finding a new market, new industries or business. Nevertheless, the businesses are restricted by 
scarce resources and a lack of capital, knowledge and technology. Thus, the next growth phase must be realised through alliances that involve the acquisition of new elements from outside to enrich growth capabilities.

Another relevant model is the Churchill and Lewis small business growth model (Churchill \& Lewis, 1983). This model consists of five stages: Stage 1-existence; Stage 2-survival; Stage 3(a)—success: disengagement; Stage 3(b)-success: growth; Stage 4-take-off; and Stage 5-resource maturity. In Stage 1 (existence), the business encounters major problems concerning finding customers and delivering products (or services) effectively and efficiently. In Stage 2 (survival), the business demonstrates its capability as an effective and workable entity in the marketplace. At this stage, the major problems shift from mere existence to maintaining the relationship between revenues and expenses to break even. Many companies remain stagnant at the survival stage for some time and earn marginal returns on invested capital and effort. Stage 3 (success) is the critical point at which important decisions must be made in terms of potential growth options. At the success stage, entrepreneurs are forced into choices about whether to pursue business growth by exploiting current business achievements and expanding the business (known as stage 3 - growth $(3 \mathrm{G})$ or to maintain company stability and profitability to support the owner's alternative activities (known as stage 3-disengage (3-D). Stage 4 (take-off) refers to the execution of rapid growth business expansion, while Stage 5 refers to the resource maturity stage. At Stage 5, the business reaches its maximum potential and becomes highly established in the market/industry. Each stage possesses unique characteristics and requires different management styles to accommodate the respective problems.

\subsection{Growth of MSEs Based on Life Cycle Models}

MSEs have the advantage of emerging as dominant start-ups in the market due to their structural flexibility and low operating costs. Based on the Greiner growth model, the birth stage is the earliest phase in the life cycle in which the business emerges and develops through the creativity of its owner (founder). In the Churchill \& Lewis model, this stage is described as at the existence stage. At this stage, the newly bred business needs external support to allow for the continuity of entrepreneurial activities. Besides that, at a later point within the phase, the business needs more support in terms of additional capital or resources as well as some sort of protection against other bigger and more established players in the marketplace, which have advantages in terms of market accessibility, a strong business network, reputation, brand and market recognition, low operating costs due to economies of scale and excessive capital and resources to support business needs and activities.

The following growth phase in the Greiner model is known as "growth through direction", while the second stage in Churchill \& Lewis' model is referred to as the survival stage. The second stage imposes different challenges on MSEs. At this stage, the businesses start expanding and most of the previous management practices and strategies become unfit to operate in the new operational context and under demands. This is the point at which entrepreneurs need professional guidance and support to ensure their ability to succeed in the growth process (Lee \& Kim, 2019). The growth challenges arise due to the disadvantages inherited by micro and small businesses (Abduh et al., 2007; Akçomak, 2009; Dhochak, Acharya, \& Sareen, 2019; Hewitt \& van Rensburg, 2020; Jacobs et al., 2017; Mazzarol, Reboud, \& Tye, 2006; Yap et al., 2019). The MSEs usually have disadvantages due to a lack of economies of scale either from the output or input sides, an absence of process and product innovations, difficulty in gaining access to tangible and intangible resources, limited access to scientific knowledge, poor management skills, and lack of know-how information (Akçomak, 2009; Dhochak et al., 2019; Ishak, Omar, Osman, Jasli, \& Hussain, 2021; Jacobs et al., 2017; Kamunge, Njeru, \& Tirimba, 2014; Mazzarol et al., 2006).

Such drawbacks may hinder future growth and lead to the collapse of the businesses. Therefore, it is not surprising that one-third of new firms do not survive in their third year and about $60 \%$ do not survive in the seventh year (Akçomak, 2009). Similarly, Hewitt and van Rensburg (2020) raised a question about the declining and missing numbers of small enterprises in South Africa after a few years of comparison. The decline phenomenon is mostly attributed to entrepreneurs' inability to deal with contextual business complexity throughout the life cycle. 
Limited capital, resource availability, business opportunities, capabilities and employee talent lead many MSEs to remain at the status quo and later diminish from the market as a result of natural selection. At this point, external support becomes crucial to complement and overcome the leadership crisis and ensure growth momentum (Ishak et al., 2021). External support plays a role in absorbing the inherited deficiencies of being "small", developing stronger entrepreneurial skills and capabilities and preparing the organisation to be an independent entity in the marketplace.

\section{DOES EXTERNAL SUPPORT MATTER?}

Currently, most development policies devote attention to strengthening micro and small enterprises as a significant source of job creation and vulnerable group empowerment. As such, many programs have been implemented to assist the development of established and resilient MSEs. Most of the programs involve the role of external support. External support refers to the assistance provided to the enterprise by external parties, including the government (Adam \& Alarifi, 202 1; Jacobs et al., 2017; Lee \& Kim, 2019; Mazzarol et al., 2006; Yap et al., 2019). Many scholars suggest a positive association between enterprise performance and external support (Adam \& Alarifi, 2021; Yap et al., 2019). MSMEs are increasingly optimising external support to provide them with the essential knowledge and capabilities necessary to improve business competitiveness and profitability. Entities such as governments, advocates and different agencies and institutions are among the parties that offer external support for MSEs to boost their growth, stimulate innovation, and enhance their capabilities by improving their managerial and marketing skills (Yap et al., 2019). Yap et al. (2019) explain that government support can be broken down into agencies and institutions that provide financial and technological assistance, consultancy, information resources, training plans, development and other aids toward entrepreneurship development. The MSEs can optimise the support received from government agencies to expand their business and acquire appropriate technology and knowledge for running businesses at their highest potential. The aid and support are classified under external support provided by various government agencies. According to Adam and Alarifi (2021) external support for MSEs may take the form of direct or indirect support. Direct external support is usually in the form of financial aid used in the acquisition of assets, purchase of technology or solutions to funding deficiency problems (Adam \& Alarifi, 2021). Most direct external support is usually provided in conjunction with specific government policies or financial intermediary conditions. Incubators are an alternative that fall under direct external support. Meanwhile, indirect external support is usually implemented in the form of consultancies, ideas and advice provided by experts, advisory offices and educational institutions to share knowledge and increase the availability of information. In the account of Mazzarol et al. (2006) business mentoring is a kind of indirect external support that facilitates the growth of small businesses through reflective guidance to resolve business problems based on mutual learning and knowledge exchange.

According to Akçomak (2009); Ayatse, Kwahar, and Iyortsuun (2017) and Pauwels, Clarysse, Wright, and Van Hove (2016) the incubator program offers an attractive framework for practitioners to deal with challenges in developing MSE ventures. The incubator serves as a remedy to overcome deficiencies encountered by MSEs through the provision of support to foster technological innovation and industrial renewal. In addition, the incubator is recognised as a mechanism for accelerating regional development through job creation, promoting the creation of new high-technology ventures, technological entrepreneurship and the transfer of technology, and dealing with market failures related to knowledge and innovative processes (Ayatse et al., 2017; Hausberg \& Korrecks, 2018). Another type of external support exercised is mentoring. Mentoring refers to a range of business advisory or counselling activities (Mazzarol et al., 2006). The business mentoring process aims to provide a means through which business problems are investigated and discussed systematically to allow business owners to develop strategies for addressing current and future business problems (Kunaka \& Moos, 2019). The relationship between the mentor and protege is based on a process of mutual knowledge exchange. The mentor is responsible for 
working out issues with their protege while guiding learning, suggesting options and assisting in the identification of further sources of resources. The proteges are supposed to find solutions for their business problems through the guidance of the mentor rather than just relying on the mentor to provide specific solutions for them. Mentoring usually becomes one of the sub-components included in the direct external support package for MSE growth and development. Figure 2 summarises the classification of the external support available for assisting MSEs' growth. As shown in Figure 2, the provider of the external support can be the government or non-government entities, such as private and non-profit organisations. As far as direct aid is concerned, the assistance usually comes in the mode of formal and structured packages, such as the incubator program, which provides the tangible and intangible resources to support business operations for a certain duration as well as imposing continual monitoring on the participants' progress or business performance. Meanwhile, the indirect mode comes in the form of sharing ideas, experience and consultancies, including the mentoring program.



Figure 2. Classification of external support for MSEs growth.

\section{THE ROLE OF INCUBATORS IN THE DEVELOPMENT OF SMALL BUSINESSES}

Business incubators are recognised as an economic and social development tool (Abduh et al., 2007; Hausberg \& Korrecks, 2018; Sedita, Apa, Bassetti, \& Grandinetti, 2018; Theodorakopoulos, Kakabadse, \& McGowan, 2014). The contribution comes through the creation of greater numbers of successful start-ups and small businesses, which enhance innovation, job creation and social cohesion. Ayatse et al. (2017) found that most studies show that the business incubation process contributes positively to participants' business performance. Incubation creates an entrepreneurial spirit to promote new venture creation while supporting economic growth and development. Moreover, knowledge flows from the external network are able to provide participants with a greater ability to avoid business failure, increase access to resource networking and funding and obtain better sales growth and survival (Ayatse et al., 2017).

The origin of the incubator began in 1959 in New York, when Joseph L. Mancuso launched the Batavia Industrial Center (Akçomak, 2009; Hackett \& Dilts, 2004; Hassan, 2020; Hausberg \& Korrecks, 2018; Hewitt \& van Rensburg, 2020; Shepard, 2013). The first incubator was established when a local real estate developer acquired a building that had been left vacant. The developer was unable to find a capable tenant to lease the entire facility, which was about 850,000 square feet. Finally, the developer opted to sublet the subdivided partitions of the building to a variety of tenants, who also requested business advice and assistance for raising capital (Hackett \& Dilts, 2004). According to Hewitt and van Rensburg (2020) at that time the basic purpose of a business incubator was to reduce the chances of failed start-ups, provide necessary support and nurture them to become resilient independent business entities. 
Nonetheless, in the mid-1990s, the number of newly established incubators in developed countries began slowing down due to problems in the incubation process, such as low-quality management advice. The importance of incubators was restored in the second half of the 1990s due to the emergence of a new high-technology economy that drove towards the creation of sector-specific incubators and virtual internet incubators aiming to stimulate networking among the high-tech start-ups. On top of that, the increase in incubators during this particular period was accelerated by the significant adoption of the incubator concept by developing countries such as China, India, Brazil, Malaysia and Turkey (Akçomak, 2009). Almost one-third of the existing incubators in developing countries were established between the early 1990s and 2000s (Akçomak, 2009; Al-Mubaraki \& Schrödl, 2013). Later, business incubators spread all over the world and were extensively used by emerging economies to support the development and growth of their small businesses (Hewitt \& van Rensburg, 2020).

The time-based chronology of business incubator development in the USA is explained in Shepard (2013) study. During the post-industrial era (the 1959-1979 cohort), the business incubator played a role as an economic development tool that aimed to reclaim derelict buildings and reduce unemployment created by suburbanisation and the concomitant exit of large industries from city centers. Most business incubators during this time performed specific tasks to assist small businesses to start and grow through a partnership between government bodies and universities. Business incubators in the first cohort provided facilities in the form of cheap rental space and management skills training. The aim was to assist participants in controlling operating costs by optimising the office space and sharing basic technologies for business operation, such as copy machines, telephones and fax machines. In the early 1980s, the USA began entering a recession period (Shepard, 2013). The US government decided to use business incubators as an economic development tool and to mitigate unemployment during this period. As a result, people began to see the value of creating and expanding new business ventures to sustain local economies, and more business incubators were established by communities to offer support for new businesses. The second generation of business incubators (the 1980-1990 cohort) provided advanced services compared to the first cohort, such as marketing training, law services and access to financial resources. Technology incubators became popular in the late 1980s, as the incubators helped their clients with research \& development (R\&D) activities, technology transfers and minimising the risk exposure of the business. The resources offered included affordable business space, clerical support, networking between tenants and communication technology. The networks were formed in formal or informal settings. The formal network setting included educational sessions and organised training, while some informal methods consisted of occupying common spaces and discussing problems in an informal setting. The third evolution of business incubators (the 2000-2012 cohort) offered a broader range of business support services, such as access to venture capital, networking and consultancy. Moreover, the era of modern incubation services offered a richer blend of offerings to assist start-up businesses, such as product design and development, manufacturing, human resources and financial management. This stage is similar to the second development cohort, but at the later stage, the services are offered in a relatively integrated mode. For instance, the professional business services provided in the business incubators include business plans, development support, counselling, coaching, mentoring and training. Business incubators also facilitate linkages between participants and appropriate networks to build their social capital. Incubators have a series of funding sources in the public, private and non-profit sectors (Shepard, 2013). A typical organisational structure for incubator development in the third cohort includes an executive and advisory board, a CEO (or the operation manager) and other support staff. The candidates of the post come from the government, educational institutions, and public and private organisations.

Based on Shepard (2013) historical review of business incubator progress in the USA, incubator establishment is to support the agenda of promoting the growth of start-ups and small businesses. Nevertheless, the emphasis of its execution is slightly different in parallel with the context at each point of time. In the first cohort, the incubator aims to assist the community with snatching up business opportunities that exist within their environment, while the second cohort's focus is encouraging the innovation and growth potential of high-prospect businesses. Finally 
the third cohort's aim is to offer assistance in building a resilient competitive advantage by offering more sophisticated and integrative professional services based on knowledge, networking and information technology to accommodate the current business environment. The chronology reiterates that MSEs normally encounter serious problems in their early life cycles. Thus, they need external support to succeed in the stages described in Greiner's growth model as "growth through creativity" and "growth through direction" —or the "existence" and "survival" stages in the Churchill and Lewis growth model. Following the three cohorts of business incubators' historical progress, more for-profit business incubators are expected to emerge in the future (Akçomak, 2009; Hewitt \& van Rensburg, 2020). The motives underlying the establishment of business incubators can be traced in a number of studies. Table 2 presents the motives behind business incubators identified in a few recent studies.

Table 2. Motives for business incubators establishment.

\begin{tabular}{|c|c|c|c|}
\hline No. & Authors & Reason & Location of case observation \\
\hline 1. & Akçomak (2009) & $\begin{array}{l}\text { 1. To reduce start-up and early stage } \\
\text { operational costs, and the risk of doing } \\
\text { business by providing a protective } \\
\text { environment for start-ups. } \\
\text { 2. As a means of regional (technology) } \\
\text { development policy. } \\
\text { 3. To enhance university-industry } \\
\text { collaboration via university incubators. } \\
\text { 4. To stimulate networking among firms } \\
\text { based on synergies among entrepreneurs } \\
\text { who share similar problems, businesses and } \\
\text { work environment. } \\
\text { 5. To reverse or prevent brain drain. }\end{array}$ & India, China, Brazil and Turkey \\
\hline 2. & $\begin{array}{l}\text { Hewitt and van } \\
\text { Rensburg (2020) }\end{array}$ & $\begin{array}{l}\text { 1. To provide support services to starts up. } \\
\text { 2. To overcome typical business challenges } \\
\text { such as financial knowledge, rental space, } \\
\text { human resources, access to market. } \\
\text { 3. Entrepreneur skills development. }\end{array}$ & South Africa \\
\hline 3. & Shepard (2013) & $\begin{array}{l}\text { 1. To nurture and develop a fledgling firm } \\
\text { to be strong enough to survive beyond } \\
\text { the first few years. }\end{array}$ & USA \\
\hline 4. & $\begin{array}{l}\text { Zapata-Guerrero } \\
\text { et al. }(2021)\end{array}$ & $\begin{array}{l}\text { 1. To accelerate growth and ensure the } \\
\text { success of entrepreneurial projects through } \\
\text { a wide range of resources and business } \\
\text { services, usually based in an educational } \\
\text { institution. }\end{array}$ & Mexico \\
\hline 5. & $\begin{array}{l}\text { Al-Mubaraki and } \\
\text { Schrödl (2013) }\end{array}$ & $\begin{array}{l}\text { 1. To produce successful firms that will } \\
\text { graduate from the program as a financially } \\
\text { viable and freestanding. }\end{array}$ & $\begin{array}{l}\text { Member of Gulf Cooperation } \\
\text { Council }\end{array}$ \\
\hline 6. & $\begin{array}{l}\text { Abduh et al. } \\
(2007)\end{array}$ & $\begin{array}{l}\text { 1. To assist the small business and new } \\
\text { start up to overcome business and } \\
\text { entrepreneurial constraints. }\end{array}$ & Australia \\
\hline
\end{tabular}

As shown in Table 2, the motives for incubator establishment center around protecting and nurturing promising MSEs to progress along the early stages of their business life cycle (Abduh et al., 2007; Akçomak, 2009; Al-Mubaraki \& Schrödl, 2013; Hewitt \& van Rensburg, 2020). In addition, incubators are meant to ensure success and accelerate the significant entrepreneurial projects (Zapata-Guerrero et al., 2021) and innovation performance of start-ups (Sedita et al., 2018). The specific implementation varies according to contextual needs. However, the basic emphasis is on two points: (1) giving aid and guidance to the selected start-up or small business to support their early existence and growth within a limited time frame, and (2) involving various external parties, including government agencies. 


\section{THE CONCEPT OF BUSINESS INCUBATORS}

\subsection{Definitions}

The incubation concept is founded on the objective of increasing the growth and survival of firms by formulating mechanisms to ensure the early identification of firms with great success potential that are restricted by the various typical constraints. Thus, the incubator concept ensures that targeted firms are able to overcome the liabilities derived from being new and small. Inevitably, profitable and sustainable ventures can be developed in the future (Ayatse et al., 2017). Hausberg and Korrecks (2018) define business incubators as business-incubating organisations that support the establishment and growth of new businesses with tangible and intangible resources throughout a flexible period with funding by a sponsor (government or corporation). Meanwhile, Pauwels et al. (2016) define incubation models as the way an incubation entity provides support to start-ups to improve the survival probability of portfolio companies and accelerate their development.

According to Shepard (2013) the basic goal for business incubators remains unchanged throughout the three cohorts of its development phase: nurturing new and fledgling businesses until they can manage on their own through the provision of technical and financial assistance at the early stage of the business cycle. Nonetheless, business characteristics are dynamic and introduce a few changes into business incubator implementation. The progress of businesses is similar to the growth of children; they are likely to grow better if they receive due care at the earliest stages of their life cycles. The incubator program gives protection and the necessary support to ensure competencies so that the business is able to survive beyond its initial years and become a resilient player after the incubation period. Al-Mubaraki and Schrödl (2013) suggest that business incubation is a support process that accelerates the successful development of start-up and fledgling companies by offering an array of resources and services to selected entrepreneurs. The services are developed by incubator management and offered either in the business incubator or through the contact network.

Originally, business incubators were defined as facilities that assist the early-stage growth of new start-ups through different services (Hassan, 2020). However, in 1988, the definition was re-defined: the purpose of the business incubator became to link technology, capital and knowledge to accelerate the growth of new companies and speed up technology transfers. Thus, a business incubator was defined as the physical location that provided a specific set of services to individuals, entrepreneurs or small companies. Incubators helped to foster innovation among start-up enterprises and enhance entrepreneurial activities. In addition, the incubator was recognised as a type of organisation specifically designed to accelerate growth and ensure the success of entrepreneurial projects through a wide range of resources and business services, usually based in educational institutions (Zapata-Guerrero et al., 2021). Abduh et al. (2007) describe business incubators as programs that target and select potential new and existing start-up ventures in the community, collocate them into a specific facility, enhance their success by providing a wide range of business assistance services and later release the participants as independent and selfsustaining business entities. The concept of business incubation also refers to a concerted, systematic effort to nurture new firms in the early stages of their activity in a controlled environment. It offers the combination of infrastructure, development-support processes and expertise needed to protect against failure and steer incubate firms' growth performance (Theodorakopoulos et al., 2014). Hackett and Dilts (2004) developed the business incubation process based on the "black box concept". The emphasis was on the relation between the events occurring inside the incubator (the internal dynamism) and its external environment. Business incubation involves a selection of incubatees from a pool of munificence of prospective candidates to enter the black box of incubation. The incubatees would undergo value-added activities in three ways: selection performance (select the weak but promising firms), monitoring and business assistance intensity, and resource munificence. Later, the incubatees would be released from the black box as financially viable and resilient firms in the market. As a result, incubators become a tool for policymakers to promote economic development and innovativeness and to catalyst the growth of new technology-based firms through the provision of services such as the following (Dhochak et al., 2019): 
(a) Access to debt and equity capital to launch and sustain the growth of clients.

(b) Establish linkages with angel, venture capital and corporate equity investors through capital networks, brokers and personal contacts.

(c) Provide quality in-house equity and debt funds to seed deals and financing gaps.

(d) Create relationships with corporations willing to provide services (e.g., manufacturing, product development, sales and distribution).

\subsection{Implementation}

The incubator concept is different from the industrial park (Hewitt \& van Rensburg, 2020). In fact, some large industrial parks have business incubators as part of the park. Business incubators promote the idea of shared administrative services, management support, linkages to capital funding sources and a conducive environment for small business cooperation and growth (Shepard, 2013). Business incubators provide support, especially to MSEs in the intermediate technology sector that require certain resources and capabilities to support the generation of competitive advantages and ensure sufficient sales levels (Zapata-Guerrero et al., 2021).

The most frequently offered services and resources are office space, legal support, networking assistance and marketing assistance (Al-Mubaraki \& Schrödl, 2013). Incubators can be categorised into different types. Akçomak (2009) divided them into for-profit and non-profit incubators. Basically, for-profit incubators involve independent entities that operate under a parent corporation.

Their main purpose is to generate revenue for the owner (the parent corporation) through various mechanisms, such as charging fees for provided services or investing in the businesses of the individual tenants. In addition, the owner (parent corporation) provides support for the tenants to achieve technological and economic goals, such as developing innovative products and processes. Most incubators in developing countries are still funded by the government, and for-profit incubators have yet to develop. On top of this, Akçomak (2009) identified four types of incubators: business innovation centres, university-based incubators, independent private incubators and corporate private incubators.

Pauwels et al. (2016) suggest that the accelerator model is an exemplar of the recent shift towards a focus on intangible, knowledge-intensive support services in the incubation program. The accelerator is described as a new generation of incubation program (Hausberg \& Korrecks, 2018). Essentially, accelerator programmes include curricula or training programs on various topics such as finance, marketing and management that the new ventures must go through when entering the program, regular counselling services, mentoring, opportunities to come into contact with customers and investors, locations and some investment opportunities for the participant firms. There are several specific features that set accelerators apart from existing incubation models:

(a) They are not primarily designed to provide physical resources or office support services over a long period of time.

(b) They typically offer pre-seed investment, usually in exchange for equity.

(c) They focus less on venture capitalists as a next step of finance but are more connected to business angels and small-scale individual investors.

(d) They emphasise business development, which aims to develop start-ups into investment-ready businesses by offering intensive mentoring sessions and networking opportunities.

(e) The model is relatively concerned with limited time support, intense interaction, monitoring and education to enable rapid progress.

To sum up, a business incubator is a concept meant to support the growth of new and small businesses, mostly at the beginning stage, by offering necessary services. The implementation may vary depending on contextual needs and business dynamics. 


\section{DISCUSSIONS}

Many MSEs have great potential to grow as profitable ventures. Nevertheless, most MSEs encounter tough obstacles to overcome after their birth and some phase out a few years after starting up. Some manage to remain at the status quo for a few years and are later eliminated due to their inability to withstand rampant business forces and crisis. The principle of natural selection allows the fittest to be sustained in the market and industry, while the weak are naturally eliminated by market forces. In parallel with the configuration perspective, external support executed in the form of entrepreneurial/business incubators becomes a solution to the typical problems faced by most MSEs at the early growth stage. Based on the Greiner Business Growth Model, at the early stage, MSEs need certain aids to successfully overcome crises occurring in the intersection between the growth through creativity and growth through direction phases. At the birth stage, micro and small businesses successfully introduce unique products or services through creative destruction activities and become profitable. Nonetheless, as the business grows, it becomes incapable of managing the environment due to the restriction of resources, capital, knowledge, talent, a managerial system and founders' incompetency. Thus, external support in the form of an incubator program can complement the deficiencies of micro and small businesses to manage the critical forces.

Similarly, based on Stage 1 of the Churchill and Lewis Growth model, new micro and small businesses usually encounter problems getting customers and delivering products or services effectively and efficiently. At this stage, competition comes from various sources, including established bigger firms. Meanwhile, in Stage 2, the major problems shift from existence to maintaining the relationship between revenue and expenses to break even. Many companies remain stagnant at the survival stage for some time and earn marginal returns from their capital investment. Therefore, external support in the form of business incubators is needed to assist in marketing and operating cost control during the critical growth stage. By integrating MSEs' growth challenges into the Greiner and Churchill \& Lewis models, we propose that the growth stages can be further classified into (1) early growth, (2) mid-growth and (3) advanced growth according to similarities in the problems and needs at each stage (see Figure 3). The early growth stage includes the first two stages of respective life cycle models. The first two stages (referring to the growth through creativity and growth through direction phases in Greiner's model and existence and survival stages in Churchill \& Lewis model, respectively) are most critical to most MSEs since their existence in the market is relatively unstable, weak and insecure. Meanwhile, the subsequent phase (known as growth through delegation and coordination in Greiner and the success stage in Churchill \& Lewis model) is recognised as the mid-growth stage. At mid-growth, the MSEs achieve a level of success in their market niche and are stronger compared to the early growth.

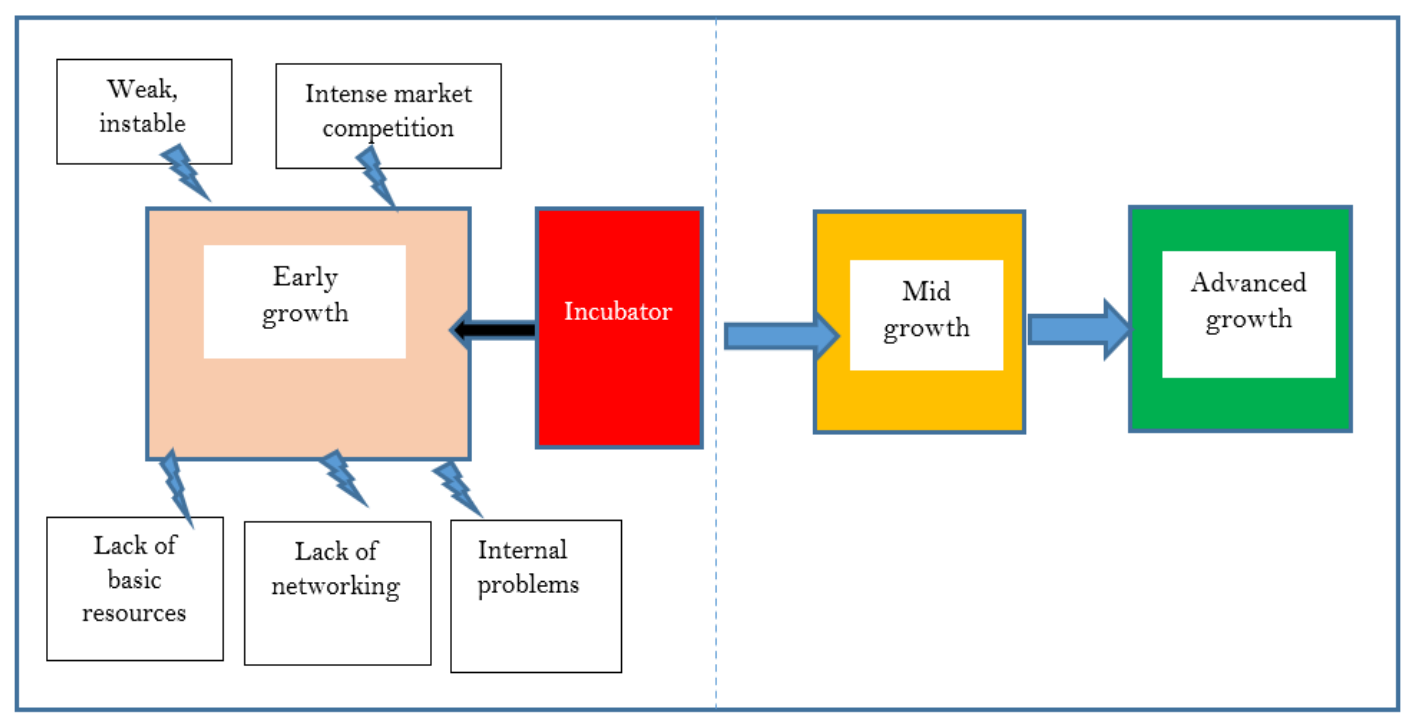

Figure 3. Life cycle of MSEs. 
Finally, advanced growth includes growth through collaboration and alliance in the Greiner model and take-off and resource maturity stages in the Churchill \& Lewis model. At the advanced growth level, MSEs reach their maximum potential in their current business and start looking forward to finding a new market or business/sector or expanding existing business radically. As shown in Figure 3, early growth is the most critical point for MSEs' future. Survival in the early growth stage provides them with essential capabilities to move to a higher growth stage. By succeeding in early growth, the MSEs can persist in the market for longer periods, provided that the economic situation remains stable and calm. Nevertheless, to succeed in the early growth stage, MSEs encounter many obstacles, such as a lack of basic resources, networking, internal management and operational problems, instability and aggressive competition from other market players, ranging from small to bigger established companies. As a result, external support, namely the incubator, is necessary.

The business incubator helps by giving necessary aid, guidance and/or protection to the selected MSEs Figure 3. The business entities that enroll in the incubator program will undergo a development process for a certain period under the particular agency.

Based on the entire review of the concept of business incubators, some points pertaining to the business incubator can be highlighted as follows:

(a) It is a method for grooming and nurturing micro or small businesses in a systematic environment for a specific period.

(b) It is offered selectively, in that the participants must fulfill certain requirements stated by the organiser. Basically, the program searches for high-potential growth candidates.

(c) It is managed by a specific management team. The sponsor can be a profit or non-profit party that offers external support for selected small businesses.

(d) Its implementation is tailored according to contextual needs in terms of the most significant forces threatening the micro or small businesses' growth; external forces (trends) that threaten the competitiveness of the microsmall businesses; and the characteristics of the participants. Thus, the execution is not restricted within a rigid template.

(e) Services offered may include basic business facilities, such as space and building occupancy with low rates or special rates, professional services including mentoring and training, networking and technology. It involves many parties that contribute to the success of the program in their respective areas of expertise.



Based on the narrative review, a typology that reflects the business incubator concept is derived and shown in Figure 4. The typology is built based on the level of incubator supervision (guidance or monitoring) of the participants and the range of services offered. The level of incubator supervision (guidance or monitoring) may 
range between tight/high monitoring to loose/low monitoring. Meanwhile, the services may range between limited/low services (only a few or basic services) to varieties of services. The variety of offerings may depend on the specific context and the objectives of the incubator agencies. In Quadrant A, the incubator program provides limited services (only a few benefits, such as training or technology support) but is given at a close level of supervision. In this quadrant, the management of the incubator provides close guidance and/or observes closely the performance of its participants. In Quadrant B, the incubator provides limited services with loose supervision. In this quadrant, the participants work as simply other independent entities and are not frequently interrupted by incubator activities. Meanwhile, in Quadrant C, the incubator program provides a large variety of services and participants are supervised closely. The services range from facilities, networking, professional services, marketing, technology and others to support the growth of the business in a holistic manner. The guidance is high because the organiser regularly monitors the progress and requires participants to give reports and/or attend specific programs compulsorily. The new generation of business incubators fits in Quadrant C. Finally, in Quadrant D, the incubator provides a high variety of services but with loose guidance supervision. Nevertheless, the participants must act wisely to optimise the incubator's services and fulfill their growth needs.

\subsection{Implications for Future Studies}

Based on this review, future studies should integrate participants in business/entrepreneurial incubator programs when studying the performance of MSEs. Due to the aid and support given to the selected participants, it is posited that incubatees are able to outperform their counterparts who are not involved in the program. It would be worthwhile to examine whether the external support, namely the incubator program, is significant for microsmall businesses' growth in their early life cycle. Additionally, future studies may examine the performance of the incubatees and non-incubatee MSE groups or the growth determinants in which the incubatees are treated as a control group. Based on the identified quadrants, future studies should not restrict the operational definition of the incubator to a standard scope. Incubator services may differ according to context. Nevertheless, the operationalisation of the incubator concept can be made within certain basic concepts: the program provides certain benefits to support business operations and involves selective participants within a limited time frame. On top of that, future researchers could conduct a specific study to evaluate the performance of incubators and identify critical factors that contribute to the performance of the incubator program.

\section{CONCLUSION}

According to the configuration perspective, business growth can be agglomerated into different stages. Each stage imposes different challenges and needs. As for MSEs, many are relatively able to accomplish a start-up (birth stage), but their subsequent growth is slightly uncertain. Some remain at the quo status and the worst are eliminated by market forces. As a result, external support is necessary to overcome MSEs' weaknesses so that highgrowth prospect firms can thrive in the market. The external support empowers the target businesses with the relevant competencies and necessary infrastructure for growth. External support in the form of business incubators provide services and/or protection for the new firms to build their competencies before releasing them as stronger, independent players in the marketplace. The incubator concept is centered around providing basic and specific amenities/services to support selected MSEs in managing their businesses efficiently and effectively. Thus, four typologies were identified based on the degree of supervision and range of services offered by the incubator program.

Funding: This study is funded by the Malaysian Ministry of Higher Education through the Fundamental Research Grant Scheme (Grant number: FRGS/ 1/2020/SSO2/UKM/O2/4).

Competing Interests: The authors declare that they have no competing interests.

Authors' Contributions: All authors contributed equally to the conception and design of the study. 


\section{REFERENCES}

Abduh, M., D'Souza, C., Quazi, A., \& Burley, H. T. (2007). Investigating and classifying clients' satisfaction with business incubator services. Managing Service Quality, 17(1), 74-91.Available at: https://doi.org/10.1 108/09604520710720683.

Adam, N. A., \& Alarifi, G. (2021). Innovation practices for survival of small and medium enterprises (SMEs) in the COVID-19 times: The role of external support. Journal of Innovation and Entrepreneurship, 10(1), 1-22.Available at: https://doi.org/10.1186/s13731-021-00156-6.

Adizes, I. (1979). Organizational passages—diagnosing and treating lifecycle problems of organizations. Organizational Dynamics, 8(1), 3-25.

Akçomak, I. S. (2009). Incubators as tools for entrepreneurship promotion in developing countries (pp. 1-36). UNU-MERIT Working Paper No. 2009-52, World Institute for Development Economics Research, Helsinki, Finland.

Al-Mubaraki, H., \& Schrödl, H. (2013). Measuring the effectiveness of business incubators: A four dimension approach from a Gulf Cooperation Council perspective. Journal of Enterprising Culture, 19(4), 435-452.

Ayatse, F. A., Kwahar, N., \& Iyortsuun, A. S. (2017). Business incubation process and firm performance: An empirical review. Journal of Global Entrepreneurship Research, 7(1), 1-17.Available at: https://doi.org/10.1186/s40497-016-0059-6.

Churchill, N. C., \& Lewis, V. L. (1983). The five stages of small business growth. Harvard Business Review, May-June, 1-11.

Dhochak, M., Acharya, S. R., \& Sareen, S. (2019). Assessing the effectiveness of business incubators. International Journal of Innovation and Learning, 26(2), 177-194.Available at: https://doi.org/10.1504/ijil.2019.10022108.

Greiner, L. E. (1998). Evolution and revolution as organizations grow. Harvard Business Review, 76(3), 55-64.

Hackett, S. M., \& Dilts, D. M. (2004). A systematic review of business incubation research. The Journal of Technology Transfer, 29(1), 55-82.Available at: https://doi.org/10.1023/b:jott.0000011181.11952.of.

Hanks, S. H., Watson, C. J., Jansen, E., \& Chandler, G. N. (1994). Tightening the life-cycle construct: A taxonomic study of growth stage configurations in high-technology organizations. Entrepreneurship theory and Practice, 18(2), 529.Available at: https://doi.org/10.1177/104225879401800201.

Hassan, N. A. (2020). University business incubators as a tool for accelerating entrepreneurship: Theoretical perspective. Review of Economics and Political Science, 1-20.Available at: https://doi.org/10.1 108/reps-10-2019-0142.

Hausberg, J. P., \& Korrecks, S. (2018). Business incubators and accelerators: A co-citation analysis based, systematic literature review. Journal of Technology Transfer, 1-26.Available at: https://doi.org/10.1007/s10961-018-9651-g.

Hewitt, L. M., \& van Rensburg, L. J. J. (2020). The role of business incubators in creating sustainable small and medium enterprises. The Southern African Journal of Entrepreneurship and Small Business Management, 12(1), 1-9.Available at: https://doi.org/10.4102/sajesbm.v12i1.295.

Ishak, S., Omar, A. R. C., Osman, L. H., Jasli, N. S. M., \& Hussain, M. Y. (2021). Single mother entrepreneurs' business growth conundrum: What matters? International Journal of Asian Social Science, 11(3), 137-153.Available at: https://doi.org/10.18488/journal.1.2021.113.137.153.

Jacobs, D., Kotzé, P., \& van der Merwe, A. (2017). A growth state transition model as driver for business process management in small medium enterprises. Paper presented at the Proceedings of the 19th International Conference on Enterprise Information Systems (ICEIS 2017).

Kamunge, M. S., Njeru, A., \& Tirimba, O. I. (2014). Factors affecting the performance of small and micro enterprises in Limuru Town Market of Kiambu County, Kenya. International Journal of Scientific and Research Publications, 4(12), 1-20.

Kunaka, C., \& Moos, M. N. (2019). Evaluating mentoring outcomes from the perspective of entrepreneurs and small business owners. The Southern African Journal of Entrepreneurship and Small Business Management, 11(1), 1-11.Available at: https://doi.org/10.4102/sajesbm.v11i1.214.

Lee, W., \& Kim, B. (2019). Business sustainability of start-ups based on government support: An empirical study of Korean startups. Sustainability, 11 (18), 1-20.Available at: https://doi.org/10.3390/su11184851.

Lester, D. L., \& Parnell, J. A. (2008). Firm size and environmental scanning pursuits across organizational life cycle stages. Journal of Small Business and Enterprise Development, 15(3), 540-554. 
Levie, J., \& Lichtenstein, B. B. (2010). A terminal assessment of stages theory: Introducing a dynamic states approach to entrepreneurship. Entrepreneurship Theory and Practice, 34(2), 317-350.Available at: https://doi.org/10.1111/j.15406520.2010.00377.x.

Mazzarol, T., Reboud, S., \& Tye, M. (2006). The outsiders role in the strategic development of the small firm: a study of mentoring with small business owner-managers in Australia. Paper presented at the Proceedings of the Annual Conference of the Administrative Science Association of Canada, Entrepreneurship and Family Business Division. Banff, Alberta: 3-6 June.

Miller, D., \& Friesen, P. H. (1984). A longitudinal study of the corporate life cycle. Management Science, 30(10), 1161-1183.

Muhos, M. (2015). Review of business growth models: Research strategies and empirical evidence. Paper presented at the Managing Intellectual Capital and Innovation for Sustainable and Inclusive Society: Managing Intellectual Capital and Innovation; Proceedings of the MakeLearn and TIIM Joint International Conference 2015 ToKnow Press.

Pauwels, C., Clarysse, B., Wright, M., \& Van Hove, J. (2016). Understanding a new generation incubation model: The accelerator. Technovation, 50-51, 13-24.Available at: https://doi.org/10.1016/j.technovation.2015.09.003.

Phelps, R., Adams, R., \& Bessant, J. (2007). Life cycles of growing organizations: A review with implications for knowledge and learning. International Journal of Management Reviews, 9(1), 1-30.

Quinn, R. E., \& Cameron, K. (1983). Organizational life cycles and shifting criteria of effectiveness: Some preliminary evidence. Management Science, 29(1), 33-51.

Scott, M., \& Bruce, R. (1987). Five stages of growth in small business. Long Range Planning, 20(3), 45-52.

Sedita, S. R., Apa, R., Bassetti, T., \& Grandinetti, R. (2018). Incubation matters: measruing the effect of business incubators on the innovation performance of start-ups. $R E \Theta^{2} D$ Management, 49(4), 439-454.Available at: https://doi.org/10.1111/radm.12321.

Shepard, J. M. (2013). Small business incubators in the USA: A historical review and preliminary research findings. Journal of Knowledge-Based Innovation in China, 5(3), 213-233.Available at: https://doi.org/10.1108/jkic-07-2013-0013.

SME Corporation Malaysia. (2018). SME annual report 2018/2019. Retrieved from: https://www.smecorp.gov.my/index.php/en/laporan-tahunan/3911-sme-annual-report-2018-2019.

Theodorakopoulos, N., Kakabadse, N. K., \& McGowan, C. (2014). What matters in business incubation? A literature review and a suggestion for situated theorising. Journal of Small Business and Enterprise Development, 21(4), 602-622.Available at: https://doi.org/10.1108/jsbed-09-2014-0152.

Yap, L. H., Syuhaimee, A., \& Hoe, C. H. (2019). Conceptual framework of the impact of external support on business performance amongst SMEs: The mediating role of organisational capability. IOSR Journal of Business and Management, 21(7), 82-87.

Zapata-Guerrero, F. T., Ayup, J., Mayer-Granados, E. L., \& Charles-Coll, J. (2021). Incubator efficiency vs survival of start-ups. RAUSP Management Journal, 55(4), 511-530.Available at: https://doi.org/10.1 108/rausp-04-2019-0063.

Views and opinions expressed in this article are the views and opinions of the author(s), International Journal of Asian Social Science shall not be responsible or answerable for any loss, damage or liability etc. caused in relation to/arising out of the use of the content. 